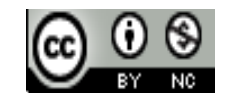

Journal of Education, Teaching, and Learning is licensed under A Creative Commons Attribution-NonCommercial 4.0 International License.

\title{
STUDENT'S COVARIATIONAL REASONING IN SOLVING Covariational Problems of Dynamic Events
}

\author{
Sandie $^{1)}$, Utin Desy Susiaty ${ }^{2)}$ \\ ${ }^{1)}$ IKIP PGRI Pontianak, Pontianak, Indonesia \\ E-mail: sandiendie@gmail.com \\ ${ }^{2)}$ IKIP PGRI Pontianak, Pontianak, Indonesia \\ E-mail: d3or4f4ty4@gmail.com
}

\begin{abstract}
One of the reasons for learners to have poor covariational reasoning is because learners understand covariation to the extent that it is procedural, while conceptually it is not fully understood. The goal to be achieved is to describe the process of student covariational reasoning in constructing graphs. This research uses a qualitative approach. This type of research is qualitative research in which the main data is written and/or spoken words. The subjects in this study were odd semester students consisting of 3, 5, and 7 Mathematics Education Study Programs, Faculty of Mathematics, Natural Sciences and Technology IKIP-PGRI Pontianak. The research instrument consists of the main instrument, namely the researcher himself and the supporting instrument, namely the task of covariational problems in the form of a written test and interview guidelines. Data analysis by processing and preparing data from the assignment results to interpreting the data and making conclusions. This study examines the process of student covariational reasoning in solving dynamic incident problems. Students initially experience a pseudo error, however, along with the problem-solving process students can eliminate pseudo thinking that was initially experienced. Students have been able to solve covariational problems at Level 5, where these problems require students to be able to coordinate changes in the value of one variable against changes in the value of other variables. The problem at level 5 also requires students to be able to see changes in time and changes in water level that occur continuously by paying attention to the irregular shape of the bottle. The existence of the Covid-19 pandemic provides a limit for researchers in collecting data that should have been done directly online. This limits researchers to dig deeper into what students think in depth. The number of students who can solve this problem needs to pay attention to the IKIP PGRI Pontianak Institute to compile a curriculum or learning media that instils the concept of reasoning.
\end{abstract}

Keywords: Dynamic Events; Covariational; Covariational Reasoning

\section{INTRODUCTION}

Theoretically, covariational reasoning competence is needed to support one's success in translating representations (Yemen-Karpuzcu et al., 2015). Therefore, it is necessary to have the ability of students to analyze the change in value patterns of one variable with other related variables in various contexts (Fennel \& Rowan, 2001). In line with this, learners need to develop a deeper understanding of understanding in analyzing patterns of change in the quantity that can be represented mathematically (Carlson et al., 2002; Johnson et al., 2017; Thompson \& Carlson, 2017). Importantly, covariational reasoning is also the basic foundation for understanding proportions (Lobato \& Siebert, 2002) ; rate of change (Gyamfi \& Bosse, 2013; Herbert \&
Pierce, 2012); variable (Dogbey, 2016); trigonometry (Moore, 2014); exponential (Ellis et al., 2015; Ellis et al., 2016); function one and two variables (Carlson, 1998; Carlson et al., 2002; Weber \& Thompson, 2014). All of these materials are evenly listed in the curriculum for the preparation of prospective teachers, especially in the field of mathematics. Therefore, covariational reasoning needs special attention in preparing prospective teachers.

To strengthen covariational reasoning competencies, Carlson et al. (2002) have created a covariational reasoning framework to examine learners' reasoning when solving dynamic event problems. Within that framework, Carlson et al. (2002) have argued that covariational reasoning is "cognitive activities involved in coordinating two varying quantities while attending to the ways in which they change 
in relation to each other". In line with thought Saldanha \& Thompson (1998) within the framework of the covariational reasoning, Carlson et al. (2002) have created 5 Levels of Covariational Reasoning supported by 5 Mental Actions which the framework forms the basis for subsequent research on covariational reasoning.

Covariational reasoning has been of particular concern to some researchers. This is indicated by the number of studies that discuss covariational reasoning. Thompson et al. (2017) have investigated the covariational reasoning of 487 teachers with details of 121 high school teachers in the USA, 366 teachers in South Korea (264 SMA, 102 SMP). Covariational reasoning research was also carried out on college students in Southwestern America (Moore, 2014; Moore \& Carlson, 2012; Paoletti \& Moore, 2017); 102 students in Australia (Wilkie, 2019); 36 students in Turkey (Yemen-Karpuzcu et al., 2015); and 15 students in Mexico (Ferrari-Escolá et al., 2016). The results showed that students, college students, and teachers still experience difficulties in solving problems that require covariational reasoning. This is caused by epistemological obstacles caused by the education system (Thompson et al., 2017).

One of the reasons learners have poor covariational reasoning is because learners understand covariation to the extent that it is procedural, while conceptually it is not fully understood. In line with this opinion, Subanji (2007) stated that: " The ability of students to interpret function graphs is still lacking, students have difficulty interpreting and representing concavities and inflection points, many students are not able to view function graphs as a representation of the relationship between two variables, it is more difficult for students to construct graphs given its analytical properties than known formulas. function, and students have difficulty in constructing a dynamic event function graph".

In line with Subanji's thought, some experts have also stated that there are still many students who do not seem to understand the reasons why from the problem-solving procedure step and do not coordinate the two changing variables simultaneously. (Carlson, 1998; Carlson et al., 2002; Moore et al., 2013). Whereas, Thompson (1994) has stated that understanding the dynamic conceptual relationship is a basic thing in linking two changes in quantity to construct an image.

From the explanation above, both representational translation and covariational reasoning are still difficult things for students, prospective teachers, students and teachers. Therefore, the preparation of covariational reasoning competencies for prospective teachers needs special attention. Hence, the thought process regarding representation translation involves covariational reasoning with the problem.

There are 2 out of 25 students who have been able to sketch graphics perfectly. The few students who were able to sketch a graph of the change in time to the height of the water in the bottle (Fig. 1), shows that the bottle problem is a serious problem for students. (Sandie et al., 2019).

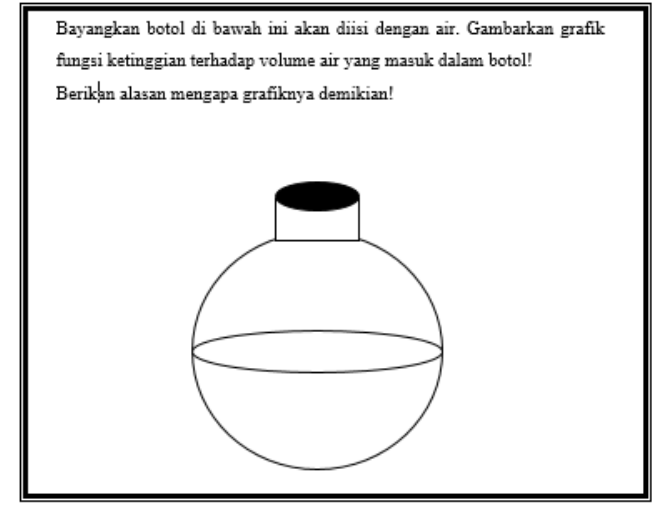

Fig. 1 The Bottle Problem (Carlson et al., 2002)

Based on the results of preliminary studies on representational translation problems that require covariational reasoning competencies from the graph to pictorial form, and from pictorial form to graphical form, it shows that students experience difficulties when students are faced with mathematical problems that contain information on the size of exact numbers. The few students who were able to solve the problem indicated that this was a serious problem for students. Given that students of the Mathematics Education study program are prospective teachers in the future and play a major role in educating and imparting concepts to students. Therefore, the process of preparing prospective teachers with good concepts needs special attention. For this reason, research on student covariational reasoning in constructing graphs.

\section{Methodology}

This research uses a qualitative approach. One of the characteristics of qualitative research is that the research process always develops dynamically, where all stages in the research process may change after the researcher enters the field and starts collecting data. For example, the individuals studied and the locations visited may also change over time (Creswell, 2014).

This research is interpretative as a whole, meaning that the researcher makes interpretations based on what is seen, heard, and understood in the field. Researchers also try to create a complex picture of the problem under study. Thus, this study provides various views regarding the interpretations of the data obtained.

This type of research is qualitative research where the main data are written and/or spoken words. Researchers studied the nature of the representation translation process which began by asking the subject to solve covariation problems from verbal forms converted into graphical and pictorial forms in writing, then continued with in-depth interviews regarding the subject's process in translating covariation problem representations from verbal to graphical forms, and from verbal form to pictorial form.

The research location was in the S1 Mathematics Education Study Program, Faculty of Mathematics, Natural Sciences and Technology IKIP-PGRI Pontianak. The research was started from April 2020 to May 2020. The 
reason for determining the place of research at IKIP-PGRI Pontianak is because the research site is a place to prepare prospective teachers who are professional in their fields, especially Mathematics Education. Therefore, preparation for the consolidation of covariational reasoning competencies of prospective teachers needs special attention.

The selection of subjects in this study were odd semester students namely 3, 5, and 7 Mathematics Education Study Program, Faculty of Mathematics, Natural Sciences and Technology IKIP-PGRI Pontianak. College student. The reason for researching 3rd-semester students and above is because students have taken the differential calculus course. Subjects were not selected randomly, but by considering their communication skills and ability to solve covariational problems.

A total of 40 students were given covariational problems. During the process of solving problems, all students were asked to verbalize what they thought (think aloud) while writing down their answers. After students solve the given covariational problems, researchers sort out the completeness of the data obtained through the results of student work. Researchers sorted the completeness of the data into the categories of complete and incomplete answers.

For students who do not provide complete answers, the researcher categorizes that these students are not research subjects. Meanwhile, for students who provide complete answers, the researcher categorizes that these students are prospective research subjects. Furthermore, the researcher interviewed all students who were categorized as prospective research subjects to confirm the information that the researcher thought was unclear and obtained information that had not been obtained from the student think-aloud data. When the interview process was carried out, the researcher was able to determine the right or wrong answers given by the students. If the student gives the correct answer, then the student is the subject of research. If the student gives a wrong answer, the student can reflect on his own so that the student gets the right answer. The researcher categorized these students into the category of research subjects, and students who were unable to reflect on their own by the researcher categorized them in the non-research subject category. Students reflect and give incorrect answers and the researchers categorize them as non-research subjects.

After categorizing the research subjects and not the research subjects, the researcher again saw the adequacy of the number of subjects for data analysis. If the researcher sees that the research subject is enough, then the researcher the research subject collection process is complete. If the researcher sees that the research subject is still lacking, then the researcher returns to giving covariational problems to other students with the same process until the research subject is fulfilled.
This research instrument consists of the main instrument and supporting instruments. The main instrument is the researcher himself, while the supporting instruments are the assignment of covariational problems and interview guidelines. The covariational problem task is a written test that aims to identify the translational process of covariational problem representations. This task requires students to reason optimally to solve covariational problems of dynamic events.

The research data collection was carried out through the assignment of translational representations of covariational problems, interviews and video recording. The assignment is given aims to obtain a translational process of student representation. Interviews were conducted to reveal the thought process if it was not identified through think aloud and to confirm the translation process if identified through think aloud. Video recording is done to obtain more detailed information about the student's translation process in solving covariational problems and interviews. The data collection procedure is presented in Fig. 2.

The steps are taken in analyzing research data are as follows: (1) processing and preparing data from the assignment results, video recording think aloud and interview recording for analysis, (2) making think-aloud transcriptions and interview results, (3) reading the whole data, (4) reducing data and making summaries containing content, thought processes and statements, (5) coding (categorization based on its preparation), (6) checking the validity of data, (7) analyzing interesting things, and ( 8) interpreting data and making conclusions. The complete data analysis process is presented in Fig. 3.

\section{RESULTS AND DISCUSSION}

\section{A. Results}

This research examines and describes qualitatively Student Covariational Reasoning in Solving Dynamic Incidence Covariational Problems. To describe the process of covariational reasoning, the researcher gave a dynamic incident covariational problem to 40 undergraduate students of the Mathematics Education Study Program, Faculty of Mathematics, Natural Sciences, and Technology, IKIP PGRI Pontianak with the same proportion for semesters 3, 5, and 7.

The Bottle Problem requires students to construct a graph of a dynamic event with changes that occur continuously where the change in speed increases and decreases. Students are asked to construct a graph of the change in time to the fuel level based on the incident of filling water in a spherical bottle with static water velocity. Of the 40 students who were given problems with covariational problems, only one student answered correctly. This shows that the bottle problem is a big problem for mathematics education study program students. 


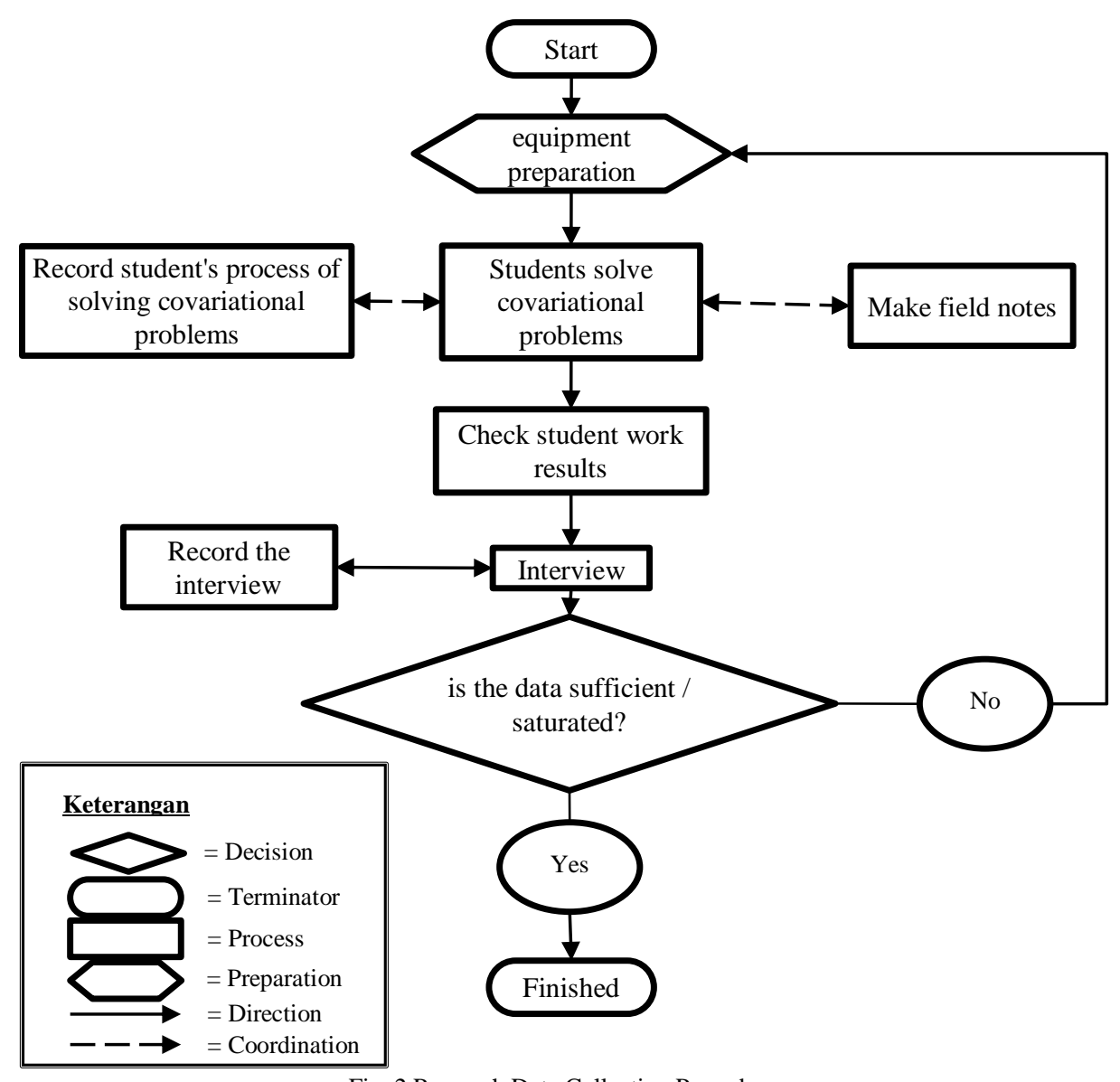

Fig. 2 Research Data Collection Procedures

There are also results of student work that can solve covariational problems are presented in Fig. 4.

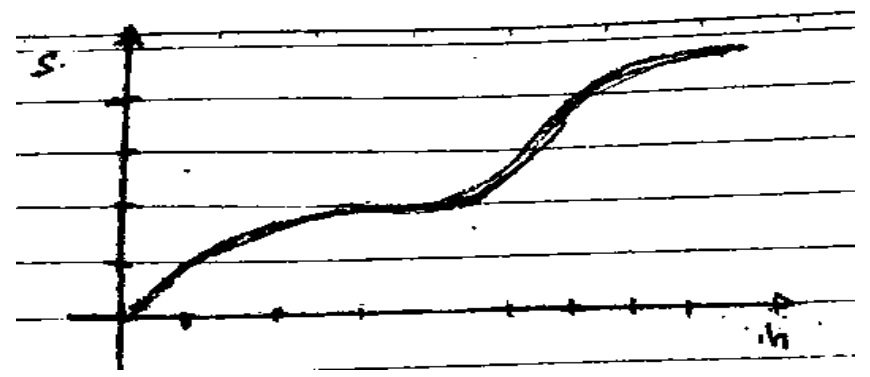

Fig 4. Student Work Results who answered Correctly

There are also reasons given by students for their work results are presented in Fig. 5.

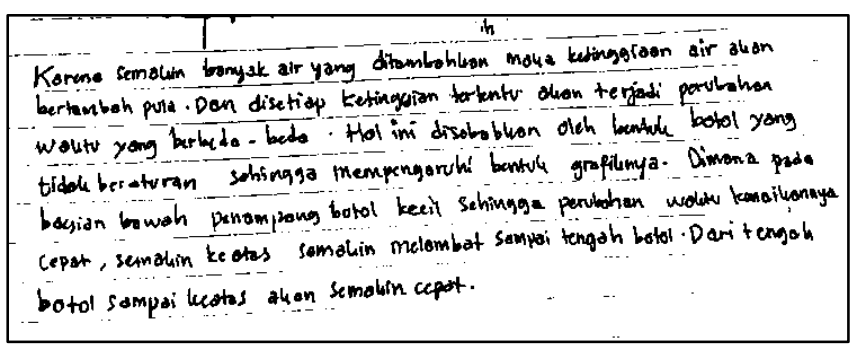

Fig. 5 The Reason For The Results Of Student Work Who Answered Correctly
A total of 40 students who were given many covariational problems could not solve the problems correctly. There are also some sample samples of student answers and their reasons are presented in Fig. 6 until Fig. 9.

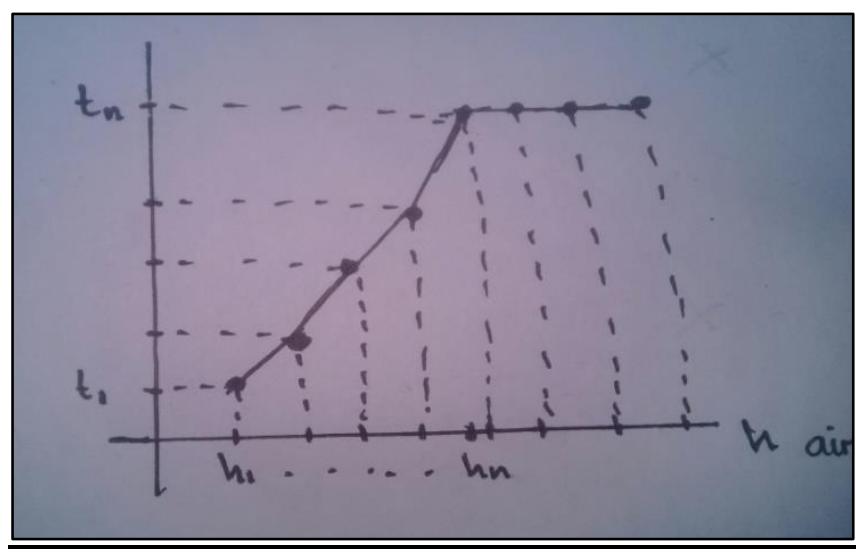

Fig. 6 Results Of Student Work Who Answered Wrong 


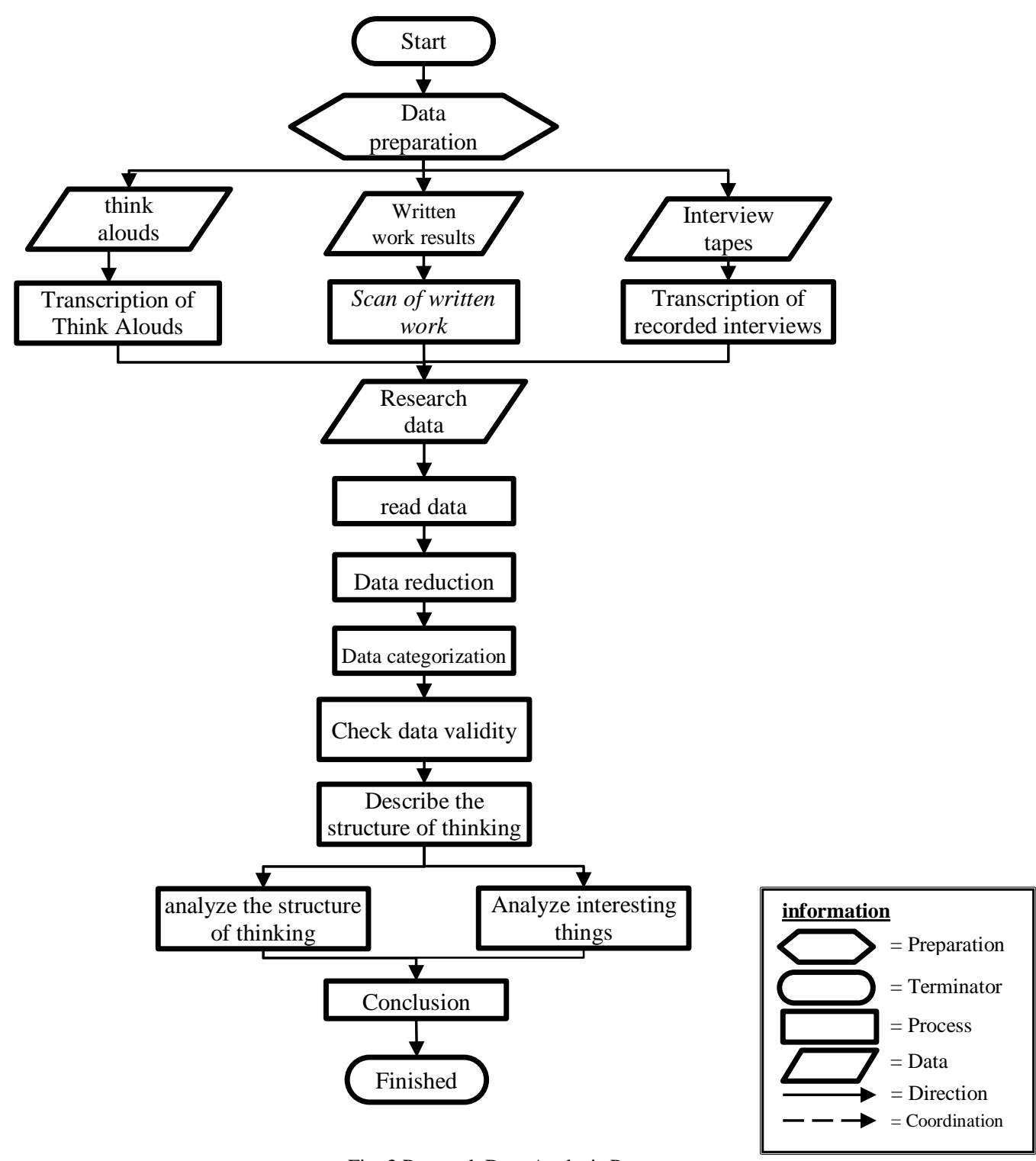

Fig. 3 Research Data Analysis Process

\section{Jawaban:}

Karena dengan waktu terhadap tinggi air dalam botol yang dimasukkan dalam botol berbanding lurus dengan rata lain semakin banyak air yang dimasukkan dalam botol maka semakin lama pula waktu yang diperlukan air dalam pengisian botol, sehingga grafik yang terbentuk berupa garis lurus dan grafik akan berubah menjadi tetap pada suatu waktu tertentu. Fig. 7 The Reason For The Results Of Student Work Who Answered Incorrectly

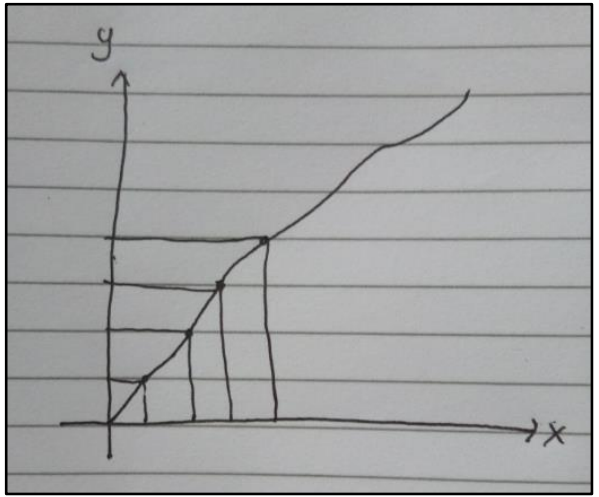

Fig. 8 Results of Student Work who answered Wrong 


\section{$\underline{\text { Jawaban: }}$ \\ Dengan diisinya air kedalam botol akan berpengaruh terhadap waktu dan ketinggian air, sehingga Semakin tinggi air maka semakin lama waktu yang diperlukan untuk mengisi botol .}

Fig 9. The Reason For The Results Of Student Work Who Answered Incorrectly

\section{B. Discussion}

Based on the presentation of the data in results, it shows that covariational problems are a big problem. Overall, the 40 students who were given the problem were only 1 person who could answer correctly. This is in line with several studies which reveal that problems requiring covariational reasoning are still an obstacle for students, students, prospective teachers and teachers both in the USA, South Korea, Australia, Turkey, and Indonesia. (Ferrari-Escolá et al., 2016; Moore, 2014; Moore \& Carlson, 2012; Moore et al., 2019; Sandie et al., 2019a; Sandie et al., 2019b; Thompson \& Carlson, 2017; Wilkie, 2019; YemenKarpuzcu et al., 2015). One of the causes of covariational problems that become a problem is reading ability (Carlson et al., 2015). Good reading skills provide understanding for a person to understand a given problem accurately. Good reading skills will also sharpen to sort out which information is meaningful and meaningless information, information that can be used to construct solutions at the planning stage of solving at the problem-solving stage (Polya, 1973).

After explaining students' difficulties in solving the bottle problem, we will discuss more deeply the student process in solving covariational problems of dynamic events which refers to the covariational reasoning framework proposed by (Carlson et al., 2002). In mental action 1 (MA1) students coordinate the value of one variable with changes in the value of other variables. At MA1, students determine which independent variable and dependent variable. The following is the results of interview research subjects who answered correctly:

Investigator: What have you understood through the information obtained on the problem?

College Student: I understand that the changes in time that occur will be different at certain altitudes.

Investigator: In your opinion, what are the dependent and independent variables in this problem?

College Student: The independent variable is the water level, while the dependent variable is the change in time. Because the water level affects the change in time.

Investigator: What is the reason?

College Student: Because the water level affects the change in time.

The results of the interview show that students are confused in determining which independent variable should be a change in time and the dependent variable is the change in water level.
After MA1 is completed, students continue to Mental Action 2 (MA2). In MA2, students can coordinate the direction of change from one variable value by paying attention to changes in values in other variables. At MA2, students realize that the direction of the graph at the time changes the higher the value is getting bigger and the direction of the graph at the water level is getting to the right the value is getting bigger and vice versa. In Mental Action 3 (MA3) students realize that the higher the water level, the more time it takes. In Mental Action 4 (MA4), students coordinate between changes in water level and changes in time. In Mental Action 5 (MA5), students can determine the curvature of the graphic which is adjusted to the shape of the bottle. At MA5, students can determine changes that occur instantaneously where the coordination between changes in water level and changes in time.

Although, the process expressed by students from MA1 to MA5 shows that time change is the dependent variable which should be an independent variable and changes in water level are independent variables that should be the dependent variable. However, based on the process of work and interviews, along with the reasons put forward by students, it shows that students understand the incident from the information provided. After being confirmed through written reasons from students in expressing their answers. The student shows that he understands the correct conditions when solving covariational problems.

There was also a reason expressed by the student, namely "this was caused by the irregular shape of the bottle that affected the graphics. Where at the bottom of the cross section of the small bottle so that the change in time increases quickly, the upward slows down to the middle. From the center of the bottle to the top the faster it will be". Based on these reasons, it can be said that at the beginning of solving problems, students experience pseudo thinking (Subanji, 2011). The pseudo that happened to these students was pseudo wrong, but the construction of knowledge when solving the problem changed from being wrong to true unconsciously.

Therefore, it is necessary to research how to make teaching materials or curricula that guide one's covariational reasoning in solving problems that require deep reasoning. This needs to be done considering that covariational reasoning is an essential competence in understanding calculus and courses with higher difficulty.

\section{CONCLUSIONS}

This study examines the process of student covariational reasoning in solving dynamic incident problems. Students initially experience a pseudo error, however, along with the problem-solving process students can eliminate pseudo thinking that was initially experienced. Students can solve covariational problems at Level 5, which requires students to be able to coordinate changes in the value of a variable against changes in the value of other variables. The problem at level 5 also requires students to be able to see changes in time and changes in water level that occur continuously by paying attention to the irregular shape of the bottle. The 
existence of the Covid-19 pandemic provides a limit for researchers in collecting data that should have been done directly online. This limits researchers to dig deeper into what students think in depth. The number of students who can solve this problem needs to pay attention to the IKIP PGRI Pontianak Institute to compile a curriculum or learning media that instils the concept of reasoning.

\section{REFERENCES}

Carlson, M. P. (1998). A cross-sectional investigation of the development of the function concept. CBMS Issues in Mathematics Education, 7, 114-162. https://doi.org/10.1090/cbmath/007/04

Carlson, M. P., Jacobs, S., Coe, E., Larsen, S., \& Hsu, E. (2002). Applying Covariational Reasoning While Modeling Dynamic Events: A Framework and a Study. Journal for Research in Mathematics Education, 33(5), 352. https://doi.org/10.2307/4149958

Carlson, M. P., Madison, B., \& West, R. D. (2015). A Study of Students' Readiness to Learn Calculus. International Journal of Research in Undergraduate Mathematics Education, 1(2), 209233. https://doi.org/10.1007/s40753-015-0013-y

Creswell, J. W. (2014). Research Design: Qualitative, Quantitative, and Mixed Methods Approaches (Fourth Edi; V. Knight, J. Young, K. Koscielak, B. Bauhaus, \& M. Markanich, eds.). Washington, DC: SAGE Publication.

Dogbey, J. (2016). Using Variables in School Mathematics: Do School Mathematics Curricula Provide Support for Teachers? International Journal of Science and Mathematics Education, 14(6), 1175-1196. https://doi.org/10.1007/s10763-015-9643-4

Ellis, A. B., Ozgur, Z., Kulow, T., Dogan, M. F., \& Amidon, J. (2016). An Exponential Growth Learning Trajectory: Students' Emerging Understanding of Exponential Growth Through Covariation. Mathematical Thinking and Learning, 18(3), 151181. https://doi.org/10.1080/10986065.2016.1183090

Ellis, A. B., Özgür, Z., Kulow, T., Williams, C. C., \& Amidon, J. (2015). Quantifying exponential growth: Three conceptual shifts in coordinating multiplicative and additive growth. Journal of Mathematical Behavior, 39, 135-155. https://doi.org/10.1016/j.jmathb.2015.06.004

Fennel, F., \& Rowan, T. (2001). Representation: An important process for teaching and learning mathematics. Teaching Children Mathematics, 7(5), 288-292.

Ferrari-Escolá, M., Martínez-Sierra, G., \& Méndez-Guevara, M. E. M. (2016). "Multiply by adding": Development of logarithmic-exponential covariational reasoning in high school students. Journal of Mathematical Behavior, 42, 92-108. https://doi.org/10.1016/j.jmathb.2016.03.003

Gyamfi, K. ., \& Bosse, M. . (2013). Processes and
Reasoning in Representations of Linear Functions. International Journal of Science and Mathematics Education, 12(1), 167-192. https://doi.org/10.1007/s10763-013-9416-x

Herbert, S., \& Pierce, R. (2012). Revealing educationally critical aspects of rate. Educational Studies in Mathematics, 81(1), 85-101. https://doi.org/10.1007/s10649-011-9368-4

Johnson, H. L., McClintock, E., \& Hornbein, P. (2017). Ferris wheels and filling bottles: a case of a student's transfer of covariational reasoning across tasks with different backgrounds and features. ZDM - Mathematics Education, 49(6), 851-864. https://doi.org/10.1007/s11858-017-0866-4

Lobato, J., \& Siebert, D. (2002). Quantitative reasoning in a reconceived view of transfer. Journal of Mathematical Behavior, 21(1), 87-116. https://doi.org/10.1016/S0732-3123(02)00105-0

Moore, K. C. (2014). Quantitative Reasoning and the Sine Function: The Case of Zac. Journal for Research in Mathematics Education, 45(1), 102. https://doi.org/10.5951/jresematheduc.45.1.0102

Moore, K. C., \& Carlson, M. P. (2012). Students' images of problem contexts when solving applied problems. Journal of Mathematical Behavior, 31(1), 48-59. https://doi.org/10.1016/j.jmathb.2011.09.001

Moore, K. C., Silverman, J., II, D. R. L., Musgrave, S., Paoletti, T., \& LaForest, K. R. (2013). Pre-service teachers ' meanings and non-canonical graphs. In M. Martines \& A. Castro Superfine (Eds.), Proceedings of the 35th annual meeting of the North American Chapter of the International Group for the Psychology of Mathematics Education (pp. 441-448). $\quad$ Retrieved from http://pmena.org/2013/proceedings.html

Moore, K. C., Stevens, I. E., Paoletti, T., Hobson, N. L. F., \& Liang, B. (2019). Pre-service teacher's figurative and operative graphing actions. The Journal of Mathematical Behavior. https://doi.org/10.1016/j.jmathb.2019.01.008

Paoletti, T., \& Moore, K. C. (2017). The parametric nature of two students' covariational reasoning. Journal of Mathematical Behavior, 48(April), 137-151. https://doi.org/10.1016/j.jmathb.2017.08.003

Polya, G. (1973). How to Solve it: A New Aspect of Mathematical Method (2nd ed.). Princeton, New Jersey: Princeton University Press.

Saldanha, L. A., \& Thompson, P. W. (1998). Re-thinking covariation from a quantitative perspective: simultaneous continuous variation. In $\mathrm{S}$. B. Berensah \& W. N. Coulombe (Eds.), Proceedings of the Annual Meeting of the Psychology of Mathematics Education - North America. Raleigh, NC: North Carolina State University.

Sandie, Purwanto, Subanji, \& Hidayanto, E. (2019a). Student Difficulties when Constructing a Hidden Bridge to Solve Dynamic Event Problems. In Habiddin, S. Majid, S. Ibnu, N. Farida, \& I. W. 
Dasna (Eds.), The 3rd International Conference on Mathematics and Sciences Education (ICoMSE) 2019 (pp. 0600261-0600265). Malang: AIP Publishing.

Sandie, S., Purwanto, P., Subanji, S., \& Hidayanto, E. (2019b). Student difficulties in solving covariational problems. International Journal of Humanities and Innovation (IJHI), 2(2), 25-30. https://doi.org/10.33750/ijhi.v2i2.38

Subanji. (2007). Proses Berpikir Penalaran Kovariasional Pseudo dalam Mengonstruksi Grafik Fungsi Kejadian Dinamik Berkebalikan. Surabaya.

Subanji. (2011). Teori Berpikir Pseudo Penalaran Kovariasional. Malang, Indonesia: UM Press.

Thompson, P. W. (1994). Students, functions, and the undergraduate curriculum. In E. Dubinsky, A. H. Schoenfeld, \& J. J. Kaput (Eds.), Research in Collegiate Mathematics Education, 4, 21-44. https://doi.org/10.2307/2687592

Thompson, P. W., \& Carlson, M. P. (2017). Variation, Covariation and Functions: Foundation ways of thinking mathematically. Compendium for Research in Mathematics Education, (January), 421-456.

Thompson, P. W., Hatfield, N. J., Yoon, H., Joshua, S., \& Byerley, C. (2017). Covariational reasoning among U.S. and South Korean secondary mathematics teachers. Journal of Mathematical Behavior, 48(August), 95-111. https://doi.org/10.1016/j.jmathb.2017.08.001

Weber, E., \& Thompson, P. W. (2014). Students' images of two-variable functions and their graphs. Educational Studies in Mathematics, 87(1), 67-85. https://doi.org/10.1007/s10649-014-9548-0

Wilkie, K. J. (2019). Investigating Students' Attention to Covariation Features of their Constructed Graphs in a Figural Pattern Generalisation Context. International Journal of Science and Mathematics Education, 47-49. https://doi.org/10.1007/s10763019-09955-6

Yemen-Karpuzcu, S., Ulusoy, F., \& Işıksal-Bostan, M. (2015). Prospective Middle School Mathematics Teachers' Covariational Reasoning for Interpreting Dynamic Events During Peer Interactions. International Journal of Science and Mathematics Education, 15(1), 89-108. https://doi.org/10.1007/s10763-015-9668-8 